\title{
Fall, CTCAE
}

National Cancer Institute

\section{Source}

National Cancer Institute. Fall, CT CAE. NCI Thesaurus. Code C143475.

A finding of sudden movement downward, usually resulting in injury. 